\title{
An Entrepreneurial Identity for Social Enterprise across the Institutional Approaches: From Mission to Accountability toward Sustainable Societal Development
}

\author{
Carla Del Gesso ${ }^{1}$ \\ ${ }^{1}$ Department of Economics, University of Molise, Campobasso, Italy \\ Correspondence: Carla Del Gesso, Department of Economics, University of Molise, Campobasso, 86100, Italy. \\ E-mail: carla.delgesso@unimol.it
}

Received: October 8, 2019

doi:10.5539/ijbm.v15n1p16
Accepted: November 10, 2019

Online Published: December 12, 2019

URL: https://doi.org/10.5539/ijbm.v15n1p16

\begin{abstract}
Social enterprise (SE) can involve any legal form of private organization, from nonprofit organizations to company forms within the business sector. This article aims to outline the entrepreneurial identity of SE, arguing that it has unique features that are independent from the organizational forms it can take. By performing crisp-set qualitative comparative analysis, this study compares the Italian legal model of SE to that of five other European countries, where national laws propose a broader institutional approach to SE. It is argued that SE, at the level of the organization, has its own entrepreneurial identity which is defined by a joint combination of five distinctive and interconnected elements that respectively connote its mission, activity, governance, performance and accountability. By systematizing these elements, it is possible to highlight how the social identification of the organization SE is the result of the interrelationship between its entrepreneurial intentions, processes and outcomes. This social identification can help to explain the crucial role that SE plays in promoting development and change in society.
\end{abstract}

Keywords: social enterprise, entrepreneurial identity, innovative entrepreneurship, fourth sector, organizational forms, social value

\section{Introduction}

Social enterprise (SE) is an emerging model for organizing entrepreneurial activity by implementing sustainable ventures explicitly designed to create social value (Austin et al., 2006; Ormiston \& Seymour, 2011). These ventures produce either financial and social returns by combining (in various ways) the economic purposes and the management skills of the business sector with the social abilities, goals and values of the social sector (Germak \& Robinson, 2014). Indeed, SE revolutionizes the traditional enterprise concept and crosses the boundaries of both the profit and nonprofit sectors (Townsend \& Hart, 2008; Dees, 2018). In recent decades, different models and typologies of SE have developed around the world, based on the influence of institutional factors and organizational interests that occur within individual socioeconomic contexts (e.g. Kerlin, 2012; Barraket et al., 2017; Defourny \& Nyssen, 2017; Hwang et al., 2017; Littlewood \& Holt, 2018).

In the international landscape moreover, there has been an increase in the number of countries that recognize SE in their legal systems, either as a unique form of organization (e.g. co-operative or charity), or rather as a legal status for a plurality of organizational forms which must fulfil some predefined requirements (Defourny \& Nyssen, 2017; Huang \& Donner, 2018). More generally, SE can represent a new legal form, or a more extended model which can involve any existing legal form of private organization, from nonprofit organizations up to and including company forms within the business sector. In some countries, as in the case of Italy, national legislation has opted for a broader concept of SE in terms of institutional acknowledgment, which can be interpreted differently according to each domestic context (Fici, 2016).

In this study it is assumed that today, SE is becoming an ever more defined entrepreneurial model which possesses distinct rules and features (McMullen, 2018), and which has gradually acquired its own business identity going beyond the organizational forms it can take or the types of model that can inspire it. However, it is believed that this identity is likely to need more detail and systematization. Indeed, although an extensive body of literature has studied the corporate phenomenon of SE, a unique and clear identity that can be independent 
from the organizational type of SE does not appear to have emerged. For this reason, drawing on identity theory, this article aims to delineate the entrepreneurial profile of SE, by providing a qualitative comparative analysis of the SE legal models of six European countries which helps to identify a set of elements that trace this profile. Thus, this analysis attempts to address the following research questions in depth:

$R Q_{1}$ : Does $\mathrm{SE}$ have its own entrepreneurial identity which goes beyond the legal forms it can take?

$R Q_{2}$ : How many and which key elements define the SE profile?

The study is motivated by the expansion of SE and the great attention it has received worldwide in both research and practice. Indeed, SE represents an important undertaking due to the growing role it plays in contributing to the social, economic and environmental development of communities, and as a result of its aptitude for tackling emerging social problems and stimulating cultural change through innovative ideas and sustainable solutions (Haugh, 2005; Kummitha, 2016; Sdrali et al., 2016). Accordingly, recognizing the unique features of the SE identity at the organizational level and thus acknowledging that one social identification can be valid for all social enterprises, may be beneficial for SE sector development which needs to broaden its organizational base.

The paper is organized in the following way: It begins with a literature review of the academic debate concerning the concepts and models of SE that are widespread worldwide. Following this, the research design is defined. The paper then explores the Italian institutional model of SE as amended by law 112/2017, outlining an entrepreneurial formula which goes beyond the legal form of organizations that are granted SE status. The subsequent section develops a comparative analysis to address the research aim, by likening the Italian legal model of SE to that of five European countries in which national laws propose a more extended model of SE. The second to last section discusses the finding and seeks to define the entrepreneurial identity of SE and finally, the article concludes, by providing the study limitations and the implications for SE research and practice.

\section{Concepts and Models of SE: A Review of the Academic Debate}

The phenomenon of SE is an emerging field of economics around the world, increasingly attracting attention among scholars, policy-makers and practitioners at an international level (e.g., Zahra et al., 2009; Lepoutre et al., 2013; Wilson \& Post, 2013; Urbano et al., 2017; Dwivedi \& Weerawardena, 2018). An extensive body of literature has investigated this phenomenon and a large variety of definitions have been proposed for the concepts of social entrepreneurship and social enterprise (Mair \& Martì, 2006; Galera \& Borzaga, 2009; Dacin et al., 2011). Both acquired relevance within academic discourse of the early 1990s and later gradually spread in various contexts of the world, arising first in the United States and continental Europe although with some divergence in emphasis, scope and understanding (Kerlin, 2006; Defourny \& Nyssen, 2010; Pestoff \& Hulgård, 2016). As highlighted by Pestoff and Hulgård (2016), the context in the United States has revealed a preference for the use of the term social entrepreneurship in its broadest sense. Whereas in continental Europe, the use of the term social enterprise has developed in reference to an organizational unit or enterprise (Borzaga \& Defourny, 2001; Defourny \& Nyssens, 2012).

The term social entrepreneurship can take on a set of meanings ranging from a narrow to broader understanding (Galera \& Borzaga, 2009). According to the narrow definition, social entrepreneurial activities are strictly located in the nonprofit sector with an explicit social mission which is supported by the opportunity to earn income. In contrast, in the broader definition, social entrepreneurship can be found in any business or setting including a capitalist economy, as long as the entity creates social value through innovation (Pestoff \& Hulgård, 2016). These two definitions are connected to the two major schools of thought in the United States, distinguished respectively by Dees and Anderson (2006) in earned income and social innovations (Defourny \& Nyssens, 2012). The notion of social entrepreneurship (in its broadest understanding) thus, can be referred to as an innovative arena of activities including a wide range of unconventional and disruptive entrepreneurial initiatives (Dees \& Anderson, 2006; Dacin et al., 2011). Consequently, social entrepreneurship implies a blurring of sector boundaries (Peredo \& McLean, 2006; Nicholls et al., 2015). In effect, these unconventional and disruptive entrepreneurial initiatives can be undertaken by individuals, profit ventures, nonprofit organizations, public agencies or by hybrid organizations mixing nonprofit and for-profit elements even in cross-sector partnership (Galera \& Borzaga, 2009). Regarding this, Dees (2018) states that the adoption of "a mission to create and sustain social value" is what distinguishes social entrepreneurs from business entrepreneurs and even from the socially responsible practice of commercial businesses (p. 39). Furthermore, as pointed out by Dacin et al. (2011), a mission aiming to create social value need not exclude the possibility of creating economic value, which is fundamental to the sustainability of social entrepreneurial ventures and of social value creation.

It is well known that SE pursues goals and social values balancing both commercial and social elements (Fitzgerald \& Shepherd, 2018) or combining aspects of the business and charity organizations at its core (Battilana 
\& Lee, 2014). It follows that the management process of SE is unique (Guo \& Bielefeld, 2014) and cannot find a suitable framework neither in the public sector and traditional nonprofit organizations, nor in conventional commercial enterprises, because of its hybrid mission of successfully achieving both "financial sustainability and social value creation" (Doherty et al., 2014, p. 429; Stevens et al., 2015). Indeed, a large body of literature has emphasized the hybrid character of SE which presents elements common to both the nonprofit sector and the for-profit sector (e.g., Austin et al., 2006; Townsend \& Hart, 2008; Battilana et al., 2015; Wry \& York, 2017).

Interestingly, the European research trajectory which inspired the EMES Research Network approach (Galera \& Borzaga, 2009; Defourny \& Nyssens, 2012) considers SE the latest innovation in the evolution of the third sector (Defourny, 2001; Defourny \& Nyssen, 2010). In effect, the third sector - which traditionally comprises nonprofit organizations and arose as an alternative to the two conventional sectors: private (businesses and profitable firms focused on the market) and public (the welfare state) - is witnessing an emerging role for socially oriented enterprises (Kramer, 2000; Laville \& Nyssens, 2001; Pestoff et al., 2012; Defourny et al., 2014). However, these enterprises are placed on the boundaries between the private sector, the public sector and the third sector, as SE joins "the commercial and social welfare logics" within an organization (Besharov \& Smith, 2014, p. 376; Wry \& York, 2017, p. 438). As noticed by Salamon and Sokolowski (2016), the third sector has become a "twilight zone" (p. 1515) in which several different institutions and activities operate, which are not merely nonprofit. Therefore, the third sector goes beyond the arenas of the market, of the state and of the nonprofit sector, and hence its boundaries appear more and more indeterminate. As mentioned by Weerawardena and Mort (2012, p. 99), the opportunity to consider a "fourth sector" appears to emerge, which includes innovative organizational forms that combine the market approach of the traditional private sector with the social and environmental aims of the public and nonprofit sectors.

In Europe, where political interest in SE has been increasing over the last two decades, there is a solid third sector tradition within which social entrepreneurial initiatives have gradually developed (Doherty et al., 2014). An important role of the third sector evolution was played by the rise of co-operative and mutual enterprises engaged in satisfying the interests of the community, improving social wealth and serving the common good (Borzaga \& Spear, 2004; Evers \& Laville, 2004). More precisely, in Europe the concept of SE first appeared in Italy with the development of social co-operatives (Defourny \& Nyssen, 2010). The latter emerged in the late 1980s in the fields of work integration and personal services with a clear entrepreneurial nature, in order to respond to community needs ill-addressed by the public sector and to close gaps within public services provision. Moreover, in 1990 in Italy a specific journal entitled "Impresa Sociale" (Social Enterprise) was created and in 1991 the Italian Parliament adopted law no. 381 which established social co-operatives as a pioneering type of SE (Poledrini, 2014). In addition, in the mid-1990s other European countries experienced the birth and spread of SE promoted by the EMES Research Network project, which aimed to encourage its legal implementation through the adoption of national laws (Defourny, 2001; Defourny \& Nyssens, 2012; Defourny et al., 2014). This also contributed to the production of clear differences, as well as similarities, in the forms of SE introduced across Europe (Spear \& Bidet, 2005).

Nonetheless, the institutional recognition of SE at national level (with appropriates laws) contributed to greater clarity for the conceptualization of SE (Kerlin, 2012; Brewer, 2016). This because, as Fici (2016) points out, an "organizational law performs a necessary and otherwise non-replaceable identifying function" (p. 650) for an organizational model like that of an SE. It should be added that there is no single and unequivocal organizational model of SE in the international framework, but many different models of SE. It is noteworthy that in recent research, Defourny and Nyssens (2017) defined four major types of SE: 1) the entrepreneurial nonprofit model, which refers to all those nonprofit organizations developing earned-income activities to integrate public grants and donations with other funding sources (according to the narrow understanding); 2) the social co-operative model, or mutual interest enterprises contributing to the general interest; 3) the social business model, which includes for-profit companies developing business activities with a social mission 4) and the public-sector social enterprise model, which embraces private enterprises initiated by public authorities who transfer to them public service provision in order to reduce public expenditure (Defourny \& Nyssens, 2017).

In short, different models of SE are developing around the world, that can take on different legal forms that vary from country to country reflecting the institutional and political environment of the individual countrywide socioeconomic contexts (Galera \& Borzaga, 2009; Kerlin, 2010; Littlewood \& Holt, 2018). The country contextual dynamics and variables are crucial for understanding the trajectories of SE development in a country (Rivera-Santos et al., 2015; Sengupta et al., 2018).

Finally, regardless of the organizational models or legal forms which are used internationally, SE appears to be unequivocally described as the use of market mechanisms to tackle social problems (Young, 2008; Kerlin, 2010). 
Furthermore, its business model tends to be framed in social innovation studies (Mulgan et al., 2007; Nicholls et al., 2015). Indeed, such entrepreneurial activity is not carried out according to the traditional logic of personal wealth accumulation but emphasizes its ability to contribute to the development of society, by producing and exchanging outputs that meet community needs or social and environmental issues (Mair \& Martì, 2006; Dacin et al., 2011). Thus, as proposed in this article, it is possible to identify a specific identity of SE with unique features that are independent from the institutional form or from the specific approach developed in the context in which the organization operates. In effect, although some single features which allow an SE identity to be defined have been separately addressed in the literature, a consistent systematization of this uniqueness that creates an overall picture of SE identification is lacking. For example, the following single features have been addressed: the particular SE mission (e.g. Doherty et al., 2014; Dees, 2018); the contribution of SE to sustainable development (Noonin, 2012; Sepulveda, 2015); the issue of SE governance (Low, 2006; Pestoff \& Hulgård, 2016); the nature of the impacts of activities (Dart, 2004; Haugh, 2006; Chell et al., 2010); and the measurement and reporting of value creation (McLoughlin et al., 2009; Gibbon \& Dey, 2011; Adams \& Simnett, 2011; Nguyen et al., 2015).

It is important to highlight that entrepreneurial identities have recently attracted scholarly attention; the literature has highlighted an opportunity to study identity (as a multi-dimensional social construct), both at the level of the individual entrepreneur and the organization, to understand who to be and what to do, or who not to be and what not to do, in relation to entrepreneurial intentions, processes and outcomes (e.g. Fauchart \& Gruber, 2011; Leitch \& Harrison, 2016; Sieger et al., 2016). In addition, although SE entrepreneurial identity is not a new question in entrepreneurship debates, the available research has focused on understanding the process by which social entrepreneurs, as founders of SE, construct their identity in terms of individual identification (Jones et al., 2008). Therefore, SE identity in terms of organizational identity remains unclear; the latter, as highlighted by Albert and Whetten (1985), is determined by what is dominant, distinctive and ongoing within an organization. Hence, consistent with this view, the present study contributes to existing knowledge by seeking to detect whether SE has its own distinctive entrepreneurial profile and what dominant elements define it $\left(R Q_{1}\right.$ and $\left.R Q_{2}\right)$.

\section{Research Design}

This study draws on the theory of identity (developed in social psychology) according to which the identity of an individual (or entity) is seen as a process of reciprocal relationships between the individual and society, with the function of positioning a person (or an entity) in the social environment, claiming their role and establishing their social recognition (e.g. Stets \& Burke, 2000; Chryssochoou, 2003; Stets \& Serpe, 2013). The core view of this theory is that identity is formed through a process of identification based on the role and position an entity has in society. Here, it may follow that the identity of SE (at the organizational level) can be independent of the organizational models and legal forms it can take, since what identifies SE is relative to society. Thus, the identity theory perspective of social identification was the starting point for this study, which aims to outline an entrepreneurial profile that can be valid for any organizational type of SE.

To address this aim and answer the research questions, the SE legal models of the following countries were analyzed: Italy, France, Finland, Lithuania, Belgium and the UK. These European countries were selected from those that opted for a broader institutional approach to SE (as a legal status), where it was not exclusively relegated to the nonprofit sector but also included company forms within the business sector. The legislative frameworks of these countries provide a more extended model of SE in different ways (Table 1). In particular, in Italy and France, SE is understood as a legal status which can be used by any legal form (e.g. associations, foundations, co-operatives and commercial companies). Also, in Finland and in Lithuania, SE is understood as a legal status which can be extended to commercial companies, but the specific laws of these countries focus narrowly on work integration. Lastly, in Belgium and the UK, SE is also understood as a legal status but it can be applied to only one legal form, namely commercial companies. 
Table 1. A broader institutional approach to SE in six European countries

\begin{tabular}{|c|c|c|c|c|}
\hline Country & Regulatory laws & SE as a legal status: & Legal forms eligible as SE & $\begin{array}{c}\text { Companies can } \\
\text { become SE? }\end{array}$ \\
\hline Italy & $\begin{array}{l}\text { Law no. } 112 \text { of } 2017 \text { on } \\
\text { Social Enterprise. }\end{array}$ & $\begin{array}{l}\text { "Qualification for all private } \\
\text { institutions". }\end{array}$ & $\begin{array}{l}\text { Status of Social enterprise may be } \\
\text { obtained by a plurality of legal forms } \\
\text { according to predefined requirements. }\end{array}$ & Yes. \\
\hline France & $\begin{array}{l}\text { Law no. } 856 \text { of } 2014 \text { on } \\
\text { Social and Solidarity } \\
\text { Economy. }\end{array}$ & $\begin{array}{l}\text { "A way of entrepreneurship } \\
\text { and economic development". }\end{array}$ & $\begin{array}{l}\text { Status of Social and Solidarity } \\
\text { Economy Enterprise can be used by } \\
\text { different legal forms with detailed } \\
\text { conditions. }\end{array}$ & Yes. \\
\hline Finland & $\begin{array}{l}\text { Law no. } 1351 \text { of } 2003 \text { on } \\
\text { Social Enterprises (amended } \\
\text { in 2007). }\end{array}$ & $\begin{array}{l}\text { "A registered trader entered } \\
\text { in the register of social } \\
\text { enterprises". }\end{array}$ & $\begin{array}{l}\text { Status of Social enterprise can be } \\
\text { adopted by any legal form of trader } \\
\text { which provides employment for the } \\
\text { disabled and long-term unemployed. }\end{array}$ & Yes. \\
\hline Lithuania & $\begin{array}{l}\text { Law no. IX-2251 of } 2004 \\
\text { (amended in 2011) on Social } \\
\text { Enterprises; Order of the } \\
\text { Minister of Economy no. } 4 \text { - } \\
207 \text { of } 2015 \text {. }\end{array}$ & $\begin{array}{l}\text { "A legal person in any legal } \\
\text { form". }\end{array}$ & $\begin{array}{l}\text { Status of Social enterprise can be } \\
\text { obtained by any legal form of } \\
\text { enterprise that is set up to create } \\
\text { employment for disadvantaged or } \\
\text { marginalized jobseekers, excluding } \\
\text { enterprises otherwise pursuing a social } \\
\text { mission if they do not employ these } \\
\text { categories of people. }\end{array}$ & Yes. \\
\hline Belgium & $\begin{array}{l}\text { Law of } 1995 \text { on Social } \\
\text { Purpose Company; Belgian } \\
\text { code on Companies- Book } \\
\text { X. }\end{array}$ & $\begin{array}{l}\text { "Companies with legal } \\
\text { personality... not dedicated to } \\
\text { the enrichment of their } \\
\text { associates". }\end{array}$ & $\begin{array}{l}\text { Status of Social Purpose Company can } \\
\text { be acquired by all forms of } \\
\text { commercial companies pursuing } \\
\text { primarily social goals. }\end{array}$ & Yes. \\
\hline UK & $\begin{array}{l}\text { Laws of } 2004 \text { on } A \\
\text { Community } \\
\text { Company (Companies Act); } \\
\text { law no. } 1788 \text { of } 2005 \\
\text { (amended in 2009). }\end{array}$ & $\begin{array}{l}\text { "A new type of } \\
\text { company...established for } \\
\text { charitable purposes". }\end{array}$ & $\begin{array}{l}\text { Status of Community Interest } \\
\text { Company can be used by } \\
\text { nonprofit-distributing companies } \\
\text { providing community benefit. }\end{array}$ & Yes. \\
\hline
\end{tabular}

Source: elaboration of the regulatory laws on SE.

The analysis of the legal status of SE in six European countries was performed in two steps. Firstly, the Italian SE legal model was examined. This is because Italy played a pioneering role in the legal implementation and development of SE in Europe by being the first to adopt a national regulation (law no. 381/1991 on social co-operative), which started the European process of institutionalizing the concept of SE (Borzaga \& Defourny, 2001). The analysis of the Italian model, in particular of the requirements that an entity should have to acquire the status of SE, led to the deduction that the dominant aspects of the model can be summarized in relation to five distinctive and consecutive factors which embrace organizational intentions, processes, and outcomes. The following factors were singled out for study: the peculiar mission of SE ("mission"); the nature of its business activity ("activity"); the related peculiarities of the management and governance systems ("governance"); the consequent impacts of activity ("performance"); and the responsibilities for reporting outcomes ("accountability").

Subsequently, these five factors were investigated within the regulatory laws on SE in France, Finland, Lithuania, Belgium and the UK, in order to be able to compare the SE legal models of the six observed countries. The laws that were considered for the study are indicated in Table 1. The results of this comparison, which highlighted similarities and differences across the six European SE legal models, were then systematized using the strategy approach of qualitative comparative analysis (QCA).

QCA is a research method that was developed in the late 1980s, by Charles Ragin to compare a limited number of case studies based on Boolean algebra and set theory; it is increasingly used in social sciences for the study of organizations due to its potential to allow researchers "to systematically examine similarities and differences of a 
set of comparable cases and identify structural conditions that lead to an outcome" (Ragin \& Rihoux, 2004; Rihoux \& De Meur, 2009, Marx et al., 2013, p. 24). The present study applied QCA in its original crisp-set version (csQCA), which is a configurational, case-oriented technique using crisp-sets (dichotomous variables); csQCA allows cases to be likened by comparing configurations of conditions in order to find combinations of conditions that generate a phenomenon (Marx et al., 2013, p. 28). Indeed, the conditions are causal variables which contribute to the explaining of an investigated outcome; thus, a link can be established between a set of conditions and a phenomenon to be explained. Both the conditions and the outcome have dichotomous configurations, in terms of presence or absence, which are expressed with Boolean values (or truth values): the value 1 is assigned to indicate a positive configuration (or presence) of the conditions and the outcome, while the value 0 is assigned to indicate their negative configuration (or absence). Boolean algebra, on whose formal language csQCA is based, uses only a binary logic and its basic logical operators are: "AND", which is a logical conjunction represented by the symbol of multiplication $(*)$; and "OR" which is a logical disjunction represented by the symbol of addition (+) (Rihoux \& De Meur, 2009, p. 35). Therefore, to perform csQCA, five significant causal conditions which might contribute to an explanation of SE identity at the organizational level were supposed as follows:
A: "mission is driven by non-profitable goals";
B: "activity addresses social/environmental matters";
C: "governance fosters worker/stakeholder involvement";
D: "performance has a social/environmental impact";
E: "accountability of social/environmental impact is a duty".

These causal conditions were identified using the results of the previous comparative investigation which was conducted across the six SE legal models in order to inspect the main distinctive aspects connoting the mission, activity, governance, performance and accountability of SE. Furthermore, these results allowed the presence or absence of each condition to be assessed and hence, values 1 or 0 (depending on whether the condition was true or false) to be assigned across the set of cases being observed. All five supposed causal conditions are significant for the achievement of the "SE entrepreneurial identity" (Y), since none of the five is individually sufficient to explain this outcome alone. Indeed, according to the csQCA approach, the outcome is achieved through conjunctural causation, where there is a sufficient combination of the conditions needed. The conditions A, B and $\mathrm{D}$ are objectively critical (necessary conditions) to explain $\mathrm{Y}$, whereas conditions $\mathrm{C}$ and $\mathrm{E}$ could be absent because their possible absence does not deny the existence of Y. Thus, the following Boolean expression was supposed:

$$
\mathrm{A} * \mathrm{~B} * \mathrm{C} * \mathrm{D} * \mathrm{E}+\mathrm{A} * \mathrm{~B} * \mathrm{c} * \mathrm{D} * \mathrm{E}+\mathrm{A} * \mathrm{~B} * \mathrm{C} * \mathrm{D} * \mathrm{e}+\mathrm{A} * \mathrm{~B} * \mathrm{c} * \mathrm{D} * \mathrm{e} \rightarrow \mathrm{Y}
$$

This formula can be read as follows: "[The presence of A, combined with the presence of $\mathrm{B}$, with the presence of $\mathrm{C}$, with the presence of $\mathrm{D}$ and with the presence of $\mathrm{E}$ ] OR [The presence of $\mathrm{A}$, combined with the presence of $\mathrm{B}$, with the absence of $\mathrm{C}$, with the presence of $\mathrm{D}$ and with the presence of $\mathrm{E}$ ] OR [The presence of A, combined with the presence of $\mathrm{B}$, with the presence of $\mathrm{C}$, with the presence of $\mathrm{D}$ and with the absence of $\mathrm{E}$ ] OR [The presence of $\mathrm{A}$, combined with the presence of $\mathrm{B}$, with the absence of $\mathrm{C}$, with the presence of $\mathrm{D}$ and with the absence of E] lead to the presence of outcome Y. Boolean minimization, which is at the heart of csQCA, then allowed this long expression to be reduced into a parsimonious expression, since the logical disjunction "OR" embodies the equifinality of conditions leading to the same outcome (Rihoux \& De Meur, 2009, p. 35). Thus, the causal conditions $\mathrm{C}$ and $\mathrm{E}$, which distinguish the four expressions of the aforementioned formula, were removed and the formula became the following:

$$
\mathrm{A} * \mathrm{~B} * \mathrm{D} \rightarrow \mathrm{Y}
$$

Consequently, based on this formula, a truth table (or table of configurations) allowed the presence of the investigated outcome $\mathrm{Y}$ to be assessed across the six case studies. Indeed, all theoretical possible combinations of condition configurations were listed in the truth table, which consisted of 32 rows $\left(=2^{5}\right.$, as 5 is the number of supposed conditions) placing both the 5 causal conditions and the outcome Y in the columns (Marx et al., 2013, p. 30); in this way, each of the six European SE legal models were placed in correspondence with one precise row, that is, one unique combination of condition configurations emerged in the truth table for each case study.

\section{The Italian Legal Model of SE}

In this section the SE legal status of Italy is analyzed. The Italian experience played an important role in the conceptualization and diffusion of SE in other countries, in and beyond Europe (Borzaga \& Defourny, 2001; 
Borzaga \& Spear, 2004; Defourny \& Nyssen, 2010). In Italy, the socioeconomic context has shown to have a traditional relationship with the social economy which has been brought about by the unsustainability and ineffectiveness of public policies. Indeed, within the third sector there has been an increase in various forms of nonprofit organization, co-operatives and social entrepreneurial initiatives, whose development has been linked to the failure of the welfare state and the subsequent emergence of the so-called welfare society (Rodger, 2000). On a legal level, the social co-operative legal form - with the emergence of which the term social enterprise took root in the Italian third sector - was introduced by law no. 381/1991. In contrast, the concept of SE (including many organizational forms for social entrepreneurial activities) was institutionalized only fifteen years later, with law no. 118/2005, legislative decree no. 155/2006 and subsequent implementation decrees of January 2008. Such legislation provided the first coherent legal framework for business activity which combined both entrepreneurial and social institution elements, with a clear distinction between traditional nonprofit organizations and traditional commercial businesses (Fici, 2016). A modern entrepreneurial dimension was introduced according to the principles of enterprise but with the explicit purpose of serving the community interest. Indeed, decree no. $155 / 2006$ established SE as an institutional formula for organizing business activities within the third sector. However, this formula was not implemented effectively and legislation on SE had to be reviewed to allow it to fully develop. Ten years later, a reform of SE was issued by law no. 106/2016 and legislative decree no. 112/2017. This reform aimed to solve the shortcomings of the previous laws, with the intention of relaunching the organizational model of SE.

In accordance with a broader understanding of SE, the Italian regulatory model for SE, passed in 2006 and reformed in 2017, states that private entities in any form can acquire the status of SE if they meet the requirements set out by the law. Such entities may carry out social, entrepreneurial activities organized in a co-operative form, in one of the forms traditionally found in the nonprofit sector (such as associations, voluntary organizations and foundations), or again in one of the many forms of commercial company. Indeed, decree no. 155/2006, with which the status for SE was established, had originally provided a regulation for "all private organizations $[\ldots]$ whose main activity is carried out in a stable way as an economic activity organized for the purpose of producing or exchanging socially beneficial goods or services, aimed at meeting goals related to general interests" (paragraph 1, section 1). This notion of SE was later improved by decree no. 112/2017 which repealed the previous decree no. 155/2006. The new status also emphasized the accountable and participatory nature of the governance of SE. According to the law, social enterprises are defined as:

"all private institutions [...] whose main activity is carried out in a stable way and is an entrepreneurial activity of general interest, without profit and for civic, solidarity and socially beneficial purposes, by adopting responsible and transparent management methods and by fostering the broadest involvement of workers, of users and others who are interested in their activities" (decree no. 112/2017, paragraph1, section1).

Decree no. 112/2017 introduced some important amendments to the previous regulatory model for SE, including extending the fields of social entrepreneurial activities that an institution may undertake in order to take on the status of an SE, allowing the possibility of distributing profits gained and providing a range of fiscal and economic incentives (Table 2). The process of institutionalization of SE within the Italian context has undergone a decisive change with the recent reform. The current regulation appears to express greater awareness and acceptance of a new way of doing business. 
Table 2. Legal recognition of SE in Italy: the main innovations introduced by the reform

\begin{tabular}{|c|c|c|}
\hline & $\begin{array}{c}\text { Previous law on SE } \\
\text { (decree no. 155/2006: "regulation of SE") }\end{array}$ & $\begin{array}{c}\text { Current law on SE } \\
\text { (decree no. 112/2017: "revision of SE regulation") }\end{array}$ \\
\hline Notion & The notion of SE is legally established. & The legal notion of SE is more clearly stated. \\
\hline Activity & A list of enterprise activities of general interest is provided. & $\begin{array}{l}\text { The previous list of enterprise activities of general interest is } \\
\text { extended. }\end{array}$ \\
\hline Aim & Social aims and absence of profit drivers are explicit. & $\begin{array}{l}\text { Social aims and absence of profit drivers are explicit and } \\
\text { declared in the notion. }\end{array}$ \\
\hline Profit distribution & $\begin{array}{l}\text { The distribution of profits gained is always forbidden among } \\
\text { the administrators, associates, members and employees of an } \\
\text { SE. }\end{array}$ & $\begin{array}{l}\text { The distribution of part of the profits gained is allowable for } \\
\text { the associates of SEs which constitute a form of a company. }\end{array}$ \\
\hline Governance & $\begin{array}{l}\text { The obligation to provide appropriate modalities for workers } \\
\text { and users involved in governance is established. }\end{array}$ & $\begin{array}{l}\text { A broadest involvement in governance is established for all } \\
\text { stakeholders, as also emphasized in the notion. }\end{array}$ \\
\hline $\begin{array}{l}\text { Financial } \\
\text { sustainability }\end{array}$ & Fiscal and financing support measures are not contemplated. & Tax advantages and financial support measures are provided. \\
\hline $\begin{array}{l}\text { Accounting and } \\
\text { Reporting }\end{array}$ & $\begin{array}{l}\text { The obligation to prepare both financial statements and social } \\
\text { reports is established. }\end{array}$ & $\begin{array}{l}\text { The obligation to prepare both financial statements and social } \\
\text { reports is reiterated and the issue of measuring and reporting } \\
\text { social impact is emphasized. }\end{array}$ \\
\hline
\end{tabular}

Source: elaboration of the Italian laws on SE.

\subsection{Business Activities of General Interest}

The Italian legislation on SE provides a list of entrepreneurial activities considered to be of general interest. This list includes multiple fields of activity, such as social and health services; education, training, and cultural activities which have educational purposes; services that safeguard and improve environmental conditions; interventions to protect cultural heritage and landscape; scientific research of particular social interest; extra-curricular training to lower school drop-out rates and enhance educational success; fair trade; microcredit; the reception and social integration of migrants; and social farming etc. According to the law these entrepreneurial activities of general interest should make up the core business when they generate at least $70 \%$ of total revenue. Furthermore, regardless of the field, enterprise activities which employ disadvantaged workers, people with disabilities and the homeless are also considered of general interest (decree no. 112/2017, paragraph 2 , sections $3 \& 4$ ). It follows that the acquisition of the status of SE by an institution depends on the nature of the activity it carries out. In particular, attention is paid to the capacity of the activity to contribute to the well-being of the community as a whole. Generally, the entrepreneurial activities are related to social issues or to fields that traditionally were an exclusive competence of the mission of the state and the public sector. Coherently, Italian legislation also established that the status of SE cannot be acquired either by institutions whose constituent acts limit the provision of goods and services exclusively in favor of their associates or members, or by companies which are made up of a single individual associate, or by public entities. Otherwise, social co-operatives (established with the law no. 381/1991) acquire the status of SE "by right".

\subsection{An Explicitly Social Mission and a Positive Social Impact}

According to the current legal notion of SE, enterprise activities of general interest pursue civic solidarity and social utility, without profitable aims. In other words, this notion states clearly that SE has a social mission and that it cannot search for gain to satisfy the self-interest of its owners. Indeed, in the Italian legislation on SE, the profits gained by the institution must be destined to carry out its statutory activity or to increase the firm's assets. However, the impossibility of distributing profits has accounted for one of the main obstacles for the full development of SE following the first regulation constituted in 2006. For this reason, the later decree no. 112/2017 provided an exception to this, by introducing the possibility of distributing a share of less than $50 \%$ of profits in favor of the company associates. This option aims to encourage the establishment of SE in the form of companies, given that Italian SE has traditionally developed in the form of co-operatives.

Moreover, in order to encourage the constitution and development of SE, the reform also introduced various economic and fiscal measures for supporting financial sustainability. For example, the introduction of the possibility of accessing funds collected through online portals and the provision of specific tax advantages for SE and for all those who invest in it. The most important advantage, among these financial sustainability measures, is 
the non-taxation of profits gained by the SE when the institution allocates them to the realization of its statutory activity or to increase the firm's assets. This reinforces the nonprofit features of the Italian model of SE, because this should encourage the institution not to distribute its profits but to reinvest them in the activity of general interest. Thus, the introduction of financial sustainability measures aims to support the social mission of SE by having faith in the positive impact on the community which is generated by the carrying out of statutory activities of general interest. Indeed, the reform tends to emphasize social impact as the crucial aim of SE, which therefore inevitably involves the need to measure and report it. Regarding reporting, decree no. 112/2017 reiterates the obligation to provide social in addition to financial reporting. According to the new law, social reports must be produced and published on the SE website "for the purpose of assessing the social impact of the activities carried out" (decree no. 112/2017, paragraph 9, section 2).

Finally, the analysis of the Italian legal model of SE highlights that the main distinctive aspects which characterize SE at the organizational level can refer to: the non-profitable purposes of social value creation that an SE entity must pursue; the nature of the entrepreneurial activities that SE carries out to achieve these purposes; the governance provisions that SE must eventually adopt to conduct their activities to achieve these purposes; the positive impacts on the community as a result of the activities performed; and the measurement and reporting of these impacts that SE must provide in order to evaluate performance results. Consequently, five consecutive factors on which to focus can be taken from the analysis of the legal status of Italian SE: mission, activity, governance, performance and accountability.

\section{Comparative Analysis and Findings}

In this section the SE legal status of Italy is compared to that in France, Finland, Lithuania, Belgium and the UK. The analysis is based on five factors (mission, activity, governance, performance and accountability) which were investigated within their respective SE legal frameworks. The results of the comparison are shown in Table 3, which summarizes the main aspects that characterize the SE legal models in relation to these factors across the six case studies. As can be seen in this table, several similarities emerged between the six national SE legal models. They mainly concern the fact that SE is driven by social aims; the fact that the business activities meet social needs or community interests; and the fact that the business activity produces results that are beneficial to society overall. In contrast, some differences also emerged. For example, the presence of participatory governance was noted, which is clearly required in some legal models and not in others, and likewise, a non-financial report was necessary in some countries. 
Table 3. Comparing the SE legal status of Italy, France, Finland, Lithuania Belgium and UK

\begin{tabular}{|c|c|c|c|c|c|}
\hline $\begin{array}{c}\text { SE legal } \\
\text { status }\end{array}$ & Mission & Activity & Governance & Performance & Accountability \\
\hline Italian & $\begin{array}{ll}\text { Nonprofit } & \text { civic, } \\
\text { solidarity and } & \text { social } \\
\text { utility purposes. } & \end{array}$ & $\begin{array}{l}\text { Many activities of } \\
\text { general interest. }\end{array}$ & $\begin{array}{l}\text { Broadest involvement } \\
\text { of workers, users and } \\
\text { other stakeholders. }\end{array}$ & $\begin{array}{l}\text { Performance as the } \\
\text { social impact of the } \\
\text { activities carried out. }\end{array}$ & $\begin{array}{l}\text { Social report must } \\
\text { integrate financial } \\
\text { reporting. }\end{array}$ \\
\hline France & $\begin{array}{l}\text { Social and solidarity } \\
\text { utility purposes, } \\
\text { different from profit } \\
\text { goals. }\end{array}$ & $\begin{array}{l}\text { Activities of: economic } \\
\text { and social support to } \\
\text { vulnerable people; } \\
\text { combating health, } \\
\text { social, economic and } \\
\text { cultural inequalities; } \\
\text { contributing to } \\
\text { sustainable } \\
\text { development. }\end{array}$ & $\begin{array}{l}\text { Democratic } \\
\text { governance providing } \\
\text { for information and } \\
\text { participation of } \\
\text { associates, workers and } \\
\text { stakeholders. }\end{array}$ & $\begin{array}{l}\text { Performance } \\
\text { development of the } \\
\text { social and solidarity } \\
\text { economy. }\end{array}$ & $\begin{array}{l}\text { Non-financial } \\
\text { disclosures must be } \\
\text { presented and debated } \\
\text { at the annual general } \\
\text { meeting. }\end{array}$ \\
\hline Finland & $\begin{array}{l}\text { Employ people in a } \\
\text { poor labor market } \\
\text { position. }\end{array}$ & $\begin{array}{l}\text { Any activity to } \\
\text { produce goods and } \\
\text { services based on } \\
\text { commercial principles } \\
\text { that employs at least } \\
30 \% \text { of people who are } \\
\text { disadvantaged or } \\
\text { long-term unemployed. }\end{array}$ & $\begin{array}{l}\text { Participatory structure } \\
\text { is not required but it is } \\
\text { not restricted. }\end{array}$ & $\begin{array}{l}\text { Performance as good } \\
\text { business practice and } \\
\text { work integration. }\end{array}$ & $\begin{array}{l}\text { Employment data and } \\
\text { any other required } \\
\text { information must be } \\
\text { provided to the } \\
\text { Ministry of Labor. }\end{array}$ \\
\hline Lithuania & $\begin{array}{l}\text { Employ disabled or } \\
\text { marginalized } \\
\text { jobseekers (target } \\
\text { group). }\end{array}$ & $\begin{array}{l}\text { SE supported } \\
\text { activities: activity } \\
\text { whose operating goals } \\
\text { pursue employment } \\
\text { and social integration } \\
\text { of target group. }\end{array}$ & $\begin{array}{l}\text { Involvement of the } \\
\text { stakeholders } \\
\text { target group. }\end{array}$ & $\begin{array}{lr}\text { Performance } & \text { as } \\
\text { development of } & \text { social } \\
\text { skills and } & \text { social } \\
\text { integration } & \text { of } \\
\text { disadvantaged } & \\
\text { jobseekers. } & \end{array}$ & $\begin{array}{l}\text { A report on the use of } \\
\text { the funds received } \\
\text { must be submitted for } \\
\text { assessment by the } \\
\text { Ministry of Social } \\
\text { Security and Labor. }\end{array}$ \\
\hline Belgian & $\begin{array}{l}\text { Social purposes, } \\
\text { without seeking the } \\
\text { enrichment of the } \\
\text { company associates. }\end{array}$ & $\begin{array}{l}\text { Any activity dedicated } \\
\text { to social purposes. }\end{array}$ & $\begin{array}{l}\text { Right of employees to } \\
\text { become associates } \\
\text { (participating in } \\
\text { decision-making). }\end{array}$ & $\begin{array}{l}\text { Performance as social } \\
\text { benefits. }\end{array}$ & $\begin{array}{l}\text { Special report on the } \\
\text { effective achievement } \\
\text { of social purpose must } \\
\text { integrate financial } \\
\text { reporting. }\end{array}$ \\
\hline UK & $\begin{array}{lr}\text { Charitable purposes } \\
\text { and cap on } \\
\text { distributions } \\
\text { interest. }\end{array}$ & $\begin{array}{l}\text { Any activity that might } \\
\text { be considered as being } \\
\text { carried out for the } \\
\text { benefit of the } \\
\text { community. }\end{array}$ & $\begin{array}{l}\text { Consultation of people } \\
\text { affected by the } \\
\text { company's activities. }\end{array}$ & $\begin{array}{l}\text { Performance as } \\
\text { providing benefit to the } \\
\text { community. }\end{array}$ & $\begin{array}{l}\text { Community interest } \\
\text { company report must } \\
\text { describe the way the } \\
\text { activities benefited the } \\
\text { community during the } \\
\text { financial year. }\end{array}$ \\
\hline
\end{tabular}

Source: elaboration of the regulatory laws for SE.

The csQCA approach allowed for the systematization of these similarities and differences in order to ascertain whether SE has its own entrepreneurial identity in terms of organizational identity, and which dominant and distinctive features define it. Thus, the status of SE in six European countries is compared based on the combination of five supposed explanatory causal conditions (see the Research design section), which are deduced using the information obtained from the analysis of the SE regulatory laws (as summarized in Table 3). In addition, based on this information, each of these five conditions (A; B; C; D; E) and the investigated outcome $(\mathrm{Y})$, which are defined as dichotomy variables in terms of their presence or absence, are assessed in relation to the legal status of SE in each of the six European countries using binary codes 1 or 0 . Indeed, a knowledge of the cases to be compared is fundamental for csQCA, as it allows for the assessment of whether a single causal condition is present or not in each case and whether a combination of condition configurations leads to the presence or absence of $\mathrm{Y}$. 
In accordance with csQCA, the truth table shows a model in which each row represents one of the thirty-two theoretical combinations of condition configurations which leads, or not, to the presence of the assessed outcome "SE entrepreneurial identity" (Table 4). As can be seen in Table 4, four SE legal models (Italian, French, Belgian, and British) are placed in one row, which corresponds to the presence of a combination of all five supposed causal conditions. Thus, in these countries, not only were the critical conditions A ("mission is driven by non-profitable goals"), B ("activity addresses social/environmental matters") and D ("performance has a social/environmental impact") present, whose combination is necessary to achieve the presence of $\mathrm{Y}$ ("SE entrepreneurial identity"), but conditions C ("governance fosters worker/stakeholder involvement") and E ("accountability of social/environmental impact is a duty") were also present, whose absence can be considered non-critical for Y. In other words, within the legal status for SE in Italy, France, Belgium and the UK, SE identity appears to be defined by a set of the same five combined elements which are independent from the peculiarities of the national contexts. Indeed, as highlighted both in Table 4 and Table 5, a value of 1 on A, on B, on C, on D and on $\mathrm{E}$ leads to the outcome value 1 in these countries, that is, the presence of $\mathrm{A}$, combined with the presence of B, C, D and E, leads to the presence of the "SE entrepreneurial identity".

Moreover, Table 4 also shows that in the truth table the SE legal models of Lithuania and Finland are placed respectively in the rows corresponding to configurations no. 6 and no. 15. In these cases, not all the five supposed causal conditions are present, although a combination of the critical conditions A, B and D is present leading to the achievement of Y. Indeed, Lithuania shows a value of 0 for condition E ("accountability of social/environmental impact is a duty"), which is absent within its SE legal model, and a value of 1 for the other four conditions, which, by contrast, are present (Table 4 and Table 5). This is because, a social report, or a non-financial report - which integrates the limited information of the traditional financial statements in order to appropriately disclose information about the impacts on the community of the entrepreneurial activity - is not required by the regulatory laws concerning SE in Lithuania. However, an additional document (a report on the use of the funds received to be submitted to the Ministry of Social Security and Labor) is required. In contrast, Finland received a value of 0 for two conditions (C and E), which are absent in its SE legal model, and a value of 1 on the other three critical conditions which, by contrast, are present (Table 4 and Table 5). This is because, like in Lithuania, the regulatory laws on SE in Finland do not require social reporting or integrated reporting, since only employment information must be provided for the Ministry of Labor; moreover, not only does condition E ("accountability of social/environmental impact is a duty") not occur, but neither does condition C ("governance fosters worker/stakeholder involvement") occur, since participatory governance is not required (although it is not restricted). However, although the absence of condition C, or condition E, or both, does not allow the identity of $\mathrm{SE}$ at the organizational level to be questioned, the presence of these conditions allows the outcome to be analyzed in a more appropriate way (here because the csQCA formula was: $\mathrm{A} * \mathrm{~B} * \mathrm{D} \rightarrow \mathrm{Y}$ ). $\mathrm{Y}$ is hereupon also present (value 1) on the row corresponding to configuration no. 4 which fulfills the csQCA formula, since the absence of condition $\mathrm{C}$ is combined with the presence of the other four conditions, leading to the presence of $\mathrm{Y}$. However, of the thirty-two theoretical configurations listed in the truth table, configuration no. 4 is the only one to delineate a causal combination which does not correspond to any of the six cases observed in this study. Nevertheless, it does correspond to a theoretical case (Table 4).

In summary, in Table 4, four rows represent different causal combinations (or causal paths) and each of these can explain the presence of the outcome "SE entrepreneurial identity"; three rows (row no. 1, row no. 6 and row no. 15) concern the six cases being observed, while one row (no. 4) concerns a theoretical case. This finding is better evident in Table 5, in which each of the six European SE legal models is associated with a precise row of configuration: four models (Italy, France, Belgium and the UK) correspond to row no. 1; one model (Lithuania) corresponds to row no. 6; and one model (Finland) corresponds to row no. 15. Therefore, a high coverage emerges, since the SE legal models with an outcome value of 1 which are covered by the relationship $A * B * D \rightarrow$ $\mathrm{Y}$ are six out of six and hence, there are no cases for which such a relationship cannot be applied. Therefore, all the cases achieve the outcome "SE entrepreneurial identity". Moreover, conditions A, B and D are always true (or present) in all models. These conditions have a very high consistency, meaning that they are necessary conditions for SE entrepreneurial identity. Indeed, the consistency measure expresses to what extent a condition is necessary to explain an outcome. Consistency for condition A, condition B and condition D is equal to 1.00 (= 6/6), which is calculated as follows: the no. of cases with a value of 1 for the condition and the outcome, divided by the total no. of cases with a value of 1 for the outcome (Rihoux and De Meur, 2009, p. 47). A high consistency also emerges for condition $\mathrm{C}$, which is equal to $0.83(=5 / 6)$; the consistency for condition $\mathrm{E}$, which is equal to $0.66(=4 / 6)$, is a little lower. Thus, all the supposed causal conditions are relevant to explain SE identity. 
Table 4. Truth table

\begin{tabular}{|c|c|c|c|c|c|c|}
\hline $\begin{array}{l}\text { Combination of } \\
\text { configurations }\end{array}$ & $\mathbf{A}$ & B & $\mathbf{C}$ & D & $\mathbf{E}$ & $\begin{array}{c}\mathbf{Y} \\
\left(\mathrm{A}^{*} \mathrm{~B} * \mathrm{D} \rightarrow \mathrm{Y}\right)\end{array}$ \\
\hline 1 & 1 & 1 & 1 & 1 & 1 & 1 (Cases: Italian, France, Belgian, UK) \\
\hline 2 & 0 & 1 & 1 & 1 & 1 & 0 (Cases: none) \\
\hline 3 & 1 & 0 & 1 & 1 & 1 & 0 (Cases: none) \\
\hline 4 & 1 & 1 & 0 & 1 & 1 & 1 (Cases: none) \\
\hline 5 & 1 & 1 & 1 & 0 & 1 & 0 (Cases: none) \\
\hline 6 & 1 & 1 & 1 & 1 & 0 & 1 (Case: Lithuania) \\
\hline 7 & 0 & 0 & 1 & 1 & 1 & 0 (Cases: none) \\
\hline 8 & 0 & 1 & 0 & 1 & 1 & 0 (Cases: none) \\
\hline 9 & 0 & 1 & 1 & 0 & 1 & 0 (Cases: none) \\
\hline 10 & 0 & 1 & 1 & 1 & 0 & 0 (Cases: none) \\
\hline 11 & 1 & 0 & 0 & 1 & 1 & 0 (Cases: none) \\
\hline 12 & 1 & 0 & 1 & 0 & 1 & 0 (Cases: none) \\
\hline 13 & 1 & 0 & 1 & 1 & 0 & 0 (Cases: none) \\
\hline 14 & 1 & 1 & 0 & 0 & 1 & 0 (Cases: none) \\
\hline 15 & 1 & 1 & 0 & 1 & 0 & 1 (Case: Finland) \\
\hline 16 & 1 & 1 & 1 & 0 & 0 & 0 (Cases: none) \\
\hline 17 & 0 & 0 & 0 & 1 & 1 & 0 (Cases: none) \\
\hline 18 & 0 & 0 & 1 & 0 & 1 & 0 (Cases: none) \\
\hline 19 & 0 & 0 & 1 & 1 & 0 & 0 (Cases: none) \\
\hline 20 & 0 & 1 & 0 & 0 & 1 & 0 (Cases: none) \\
\hline 21 & 0 & 1 & 0 & 1 & 0 & 0 (Cases: none) \\
\hline 22 & 0 & 1 & 1 & 0 & 0 & 0 (Cases: none) \\
\hline 23 & 1 & 0 & 0 & 0 & 1 & 0 (Cases: none) \\
\hline 24 & 1 & 0 & 0 & 1 & 0 & 0 (Cases: none) \\
\hline 25 & 1 & 0 & 1 & 0 & 0 & 0 (Cases: none) \\
\hline 26 & 1 & 1 & 0 & 0 & 0 & 0 (Cases: none) \\
\hline 27 & 0 & 0 & 0 & 0 & 1 & 0 (Cases: none) \\
\hline 28 & 0 & 0 & 0 & 1 & 0 & 0 (Cases: none) \\
\hline 29 & 0 & 0 & 1 & 0 & 0 & 0 (Cases: none) \\
\hline 30 & 0 & 1 & 0 & 0 & 0 & 0 (Cases: none) \\
\hline 31 & 1 & 0 & 0 & 0 & 0 & 0 (Cases: none) \\
\hline 32 & 0 & 0 & 0 & 0 & 0 & 0 (Cases: none) \\
\hline
\end{tabular}


Table 5. Crisp-set qualitative comparative analysis (csQCA)

\begin{tabular}{|c|c|c|c|c|c|c|c|}
\hline \multicolumn{8}{|c|}{ Causal conditions } \\
\hline & & A & B & $\mathrm{C}$ & $\mathrm{D}$ & E & Y \\
\hline & Cases & $\begin{array}{c}\text { Mission is } \\
\text { driven by } \\
\text { non-profitable } \\
\text { goals }\end{array}$ & $\begin{array}{c}\text { Activity addresses } \\
\text { social/ } \\
\text { environmental } \\
\text { matters }\end{array}$ & $\begin{array}{c}\text { Governance } \\
\text { fosters } \\
\text { worker/ } \\
\text { stakeholder } \\
\text { involvement }\end{array}$ & $\begin{array}{c}\text { Performance } \\
\text { has a social/ } \\
\text { environmental } \\
\text { impact }\end{array}$ & $\begin{array}{c}\text { Accountability } \\
\text { of social/ } \\
\text { environmental } \\
\text { impact is a duty }\end{array}$ & $\begin{array}{c}\text { SE entrepreneurial } \\
\text { identity } \\
\left(A^{*} B * D \rightarrow Y\right)\end{array}$ \\
\hline Row & Italian & 1 & 1 & 1 & 1 & 1 & 1 \\
\hline no. 1 & France & 1 & 1 & 1 & 1 & 1 & 1 \\
\hline & Belgian & 1 & 1 & 1 & 1 & 1 & 1 \\
\hline & $\mathrm{UK}$ & 1 & 1 & 1 & 1 & 1 & 1 \\
\hline $\begin{array}{l}\text { Row } \\
\text { no. } 6\end{array}$ & Lithuania & 1 & 1 & 1 & 1 & 0 & 1 \\
\hline $\begin{array}{l}\text { Row } \\
\text { no. } 15\end{array}$ & Finland & 1 & 1 & 0 & 1 & 0 & 1 \\
\hline
\end{tabular}

\section{Discussion of Findings: An Entrepreneurial Identity for SE?}

The comparative analysis of the legal status of SE in six European countries - including private entities in any form, from charity organizations to market-based companies - helps to reply positively to the first research question posed in this study: SE has its own entrepreneurial identity which goes beyond the legal forms it can take $\left(R Q_{l}\right)$. Indeed, this analysis leads to the assertion that what constitutes an SE entity is independent of the many different organizational forms and country models, since it concerns a combination of the entrepreneurial intention (mission), the entrepreneurial processes (activities and their management and governance), and the entrepreneurial outcomes (performance results and their accountability) of an SE venture. The results of the comparative analysis corroborate the supposition that SE has a social identification which is relative to the role it plays in society as a whole. Such identification consists of unique features which relate to its role and distinguishes SE from other organizations. Indeed, specific interrelated aspects connote:

- the mission, which is driven by non-profitable goals, where the generation of value outcomes for society are envisioned;

- the activity, which addresses social/environmental matters, where entrepreneurial activity is the means with which to generate social value outcomes, by serving society's needs;

- the governance, which fosters worker/stakeholder involvement, where an SE entity can involve in its decisions social interlocutors who are affected by, or can affect, the entrepreneurial activity so that value outcomes for society can be achieved;

- the performance, which has a social/environmental impact, where the entrepreneurial processes, aligned with the mission, achieve value outcomes which cause relevant effects on society;

- and the accountability of social/environmental impact, which is a duty, where an SE entity is responsible for disclosing complete information on the values created, in order to legitimate the intended aims, the entrepreneurial activity and the performed outcomes.

Hence, some dominant and distinctive features which describe SE identity at the organizational level can be recognized in relation to the mission, activity, governance, performance and accountability of an SE entity. The csQCA approach, which looks at the configuration of a set of elements to explain a phenomenon, was helpful for this identification process. It allowed the simultaneous presence of the above aspects of an SE mission, activity, governance, performance and accountability in the six SE legal models to be assessed; it also allowed an evaluation of how their joint presence is combined to form a necessary and sufficient set of variables leading to SE identity explanation. Indeed, the comparative analysis by way of csQCA highlighted the systemic relevance of the five aspects and the individual relevance of a single aspect in combination with others. It emerged that what connotes the entrepreneurial mission, activity and performance has the maximum consistency (= 1.00) for SE identity, meaning that the presence of each aspect is individually necessary but not enough alone to identify an 
organization as an SE. Yet, their joint presence is necessary and sufficient to identify an SE. Moreover, the high consistency of the details concerning the governance $(=0.83)$ and the accountability $(=0.66)$ shows their importance for an SE entity, meaning that they are also necessary details for SE. However, at the same time, the absence of these two factors does not compromise the SE identity.

Finally, SE has some traits and features which identify a distinct way of doing business, which is realistically valid for each socio-economic context. A combination of at least five key elements that define the SE profile $\left(R Q_{2}\right)$ can be summarized as follows:

I. A mission intended to create value outcomes for society;

II. An entrepreneurial activity with which to generate value outcomes for society;

III. A participatory governance;

IV. A multi-dimensional value of performance outcomes;

V. An integrated accountability through non-financial reporting.

\subsection{A Mission Intended to Create Value Outcomes for Society}

The entrepreneurial intention of an SE entity is not driven by a predominant desire to accumulate personal wealth in the interests of the enterprise's members like that which occurs in traditional for-profit firms. The social mission of SE is consistent with an organizational community-minded vision which entails value creation for society at large. In some way, the entrepreneurial identity of the SE founders can be linked to a "missionary identity", as SE founders undertake enterprise to promote social or environmental causes for a better society (Fauchart \& Gruber, 2011, p. 944; Sieger et al., 2016; see also Jones et al., 2008). The value creation for society of an SE entity can take place in many different ways, including creating financial value which may better support social value creation (Dees, 2018). Indeed, the sustainability of an SE entity (and thus, of its social mission) is subordinate to the achievement of positive economic and financial performance, although the SE mission is not driven by profit goals and primary motivations of individual enrichment. This is evident in all six SE legal systems observed in this study (Table 3); it is also reinforced by an explicit cap on the distribution of company profits, as in the case of Italy and the UK, for example. However, to fully identify the identity of an SE entity, its social mission needs to be considered in combination with others features, for example, with those which define the nature of the activity and the relative performance results. Indeed, the charitable goals of an SE entity, while on the one hand distinguish SE from traditional profitable firms, on the other hand unite SE with nonprofit organizations; however, at this point, the entrepreneurial nature of the activity and its performance outcomes become relevant in order to distinguish an SE entity from a nonprofit organization.

\subsection{An Entrepreneurial Activity with Which to Generate Value Outcomes for Society}

An SE entity uses entrepreneurial activity as a vehicle for sustainable societal value creation, addressing social and environmental concerns. Indeed, in pursuit of the generation of this value, SE efficiently arranges resources, capabilities and processes according to market principles to achieve performance outcomes which have a relevant social/environmental impact on the whole community. In this vein, any different durable business activities can be carried out, as is evident in the cases examined: activities of general interest (in the Italian model); activities which give support to vulnerable people and reduce inequalities (in the French model); activities which promote the integration of disadvantaged workers (in the Finnish and Lithuania legal models); and activities performed for social purposes (in the Belgian model), or for the benefit of the community (in the British model). The entrepreneurial endeavors of an SE entity, as is explicit in the French model and implicit in other models, contribute to sustainable development (Noonin, 2012; Sepulveda, 2015), tackling shared problems that touch all countries, all communities and all individuals, which would normally be the responsibility of public policy-makers. Finally, SE is a smart sustainable business model which brings benefits to society and advances the nations in which it operates, reconciling economic, social and environmental development.

\subsection{A Participatory Governance}

A participatory model for the management of the SE activities is evident in five of the six cases observed in this study. Indeed, participatory decision-making structures, in terms of involvement (as in the Italian, French, Lithuanian and Belgian legal models) or consultation (as in the British legal status) of employees and/or stakeholders affected by the SE activities, is clearly required (Table 3). It should be noted that this participatory (or democratic) form of SE governance is a specific feature of the European approach to SE (Pestoff \& Hulgård, 2016); this form is considered to be a typical model of the nonprofit sector, while an SE entity may more likely exhibit the stewardship of the profit sector (Low, 2006). However, in agreement with Pestoff \& Hulgård (2016, p. 14), a multi-stakeholder involvement in the deliberations of an SE entity could help it to better balance divergent interests, reduce potential conflicts between diverse goals and stakeholders, tackle managerial challenges and 
achieve a greater degree of social legitimacy. Finally, the way an SE entity is governed plays a decisive role in ensuring the pursuit of its social mission which, via its entrepreneurial processes, brings about societal value outcomes.

\subsection{A Multi-Dimensional Value of Performance Outcomes}

The entrepreneurial activity of an SE entity, like any business activity, generates a value whose impact on society is undoubtedly economic. However, as is known, this impact is not only economic, given that the creation of social value is the core objective of SE (e.g. Haugh, 2006; Ormiston \& Seymour, 2011). This is evident in all the legal models examined, where the impact of the activities is expressed in terms of social impact (in the Italian model), in terms of social and solidarity economy development (in the French model), in terms of social benefits (in the Belgian and British models), and in terms of work integration development (in the Finnish and Lithuanian models). Indeed, the creation of wealth by an SE entity, which seeks to interpret the social, economic and environmental needs of the territory in which it operates, aids not only the recipients of the goods/services, but the entire surrounding environment and the whole society. An SE entity produces outcomes which can also be the fostering of socio-economic progress, sustainable development, innovation and changes at a cultural and political level. Therefore, the performance results of the SE business activity match the value outcomes whose impact on society must be understood from a multi-dimensional perspective, namely economic, social, environmental, cultural, ideological, institutional and political (Dart, 2004; Chell et al., 2010).

\subsection{An Integrated Accountability through Non-Financial Reporting}

The multi-dimensional value of outcomes raises the problem of how to measure and report SE value creation (e.g. McLoughlin et al., 2009; Gibbon \& Dey, 2011; Nguyen et al., 2015). The evaluation of performance from a broader perspective necessarily implies the implementation in the SE of an integrated reporting system (Adams \& Simnett, 2011) which allows for the disclosure of non-financial dimensions of value (social, environmental, cultural etc.). As in some models analyzed in this study, SE reporting systems are based on the integration of financial and non-financial aspects of value disclosure, through the adoption of a special report which supports traditional financial reporting and increased accountability (in the Italian, French, Belgian and the British legal models). As highlighted by the International Integrated Reporting Framework (which provided principle-based guidance for an organization wishing to prepare an integrated report) any organization should inform their stakeholders about how its value was created (Integrated Reporting, 2013). This is particularly important in SE organizations (especially in those constituted in company forms), where non-financial disclosure helps to enhance the governance of social entrepreneurial activities and the accountability of the effective achievement of a social mission, by satisfying the information needs of decision-makers and the stakeholders involved. Indeed, stakeholders need a real perception of the value created through planned and achieved performance which should emerge from the overall accounting and accountability systems.

\section{Conclusion}

This study makes a contribution to the literature on SE by systematizing, through the lens of identity theory, a set of unique features which can be valid for any SE entity regardless of its organizational legal form and the socio-economic context. It first analyzed the Italian legal model for SE and then compared it with five other European country models, examining the different forms of legal status for each. Indeed, in all the countries examined, SE is a label which can be also applied to organizations constituted in company forms. However, the main limitation of this study is that it did not consider other countries in and beyond the European EMES approach, where $\mathrm{SE}$ is a legal status in a broadest sense.

Based on the findings, it was argued that SE, at the level of the organization, has its own entrepreneurial identity which is defined by a joint combination of five distinctive and interconnected elements connoting respectively its mission, activity, governance, performance and accountability. Indeed, this study has highlighted how the identity of an SE organization is the result of the interrelationship between its entrepreneurial intentions, processes and outcomes.

However, SE entrepreneurial identity, in terms of organizational identification in society, deserves further study by scholars in the fields of management and accounting. At an important and relevant time for discourses concerning social responsibility and sustainable development, studying SE identity can help to better interpret the crucial role that SE plays in contributing to a country's socio-economic progress, because of its innovative way of understanding entrepreneurship. Indeed, SE can be an effective agent of development and change in society. For this matter, the SE sector (likely an emerging fourth sector) needs to be developed fully with social entrepreneurial activities which are also organized in company forms. Such social entrepreneurial activities in company forms should be encouraged in entrepreneurial practice, as well as analyzed by entrepreneurial research in order to 
develop and disseminate best practices.

Moreover, this article hopes to raise the political and cultural awareness of policy-makers and entrepreneurs of what it means to assume an SE identity (beyond the regulatory requirements for its legal status), that is, to be an SE is to be a responsible institution for the possible and sustainable improvement of society.

\section{References}

Adams, S., \& Simnett, R. (2011). Integrated Reporting: An opportunity for Australia's not-for-profit sector. Australian Accounting Review, 21(3), 292-301.

Albert, S., \& Whetten, D. (1985). Organizational identity. In Cummings, L. L., \& Staw, B.M. (Eds.), Research in Organizational Behaviour (pp. 263- 295). Greenwich, USA: JAI Press.

Austin, J., Stevenson, H., \& Wei-Skillern, J. (2006). Social and commercial entrepreneurship: same, different, or both? Entrepreneurship Theory and Practice, 30(1), 1-22. http://dx.doi.org/10.1111/j.1540-6520.2006.00107.x

Barraket, J., Douglas, H., Eversole, R., Mason, C., McNeill, J., \& Morgan, B. (2017). Classifying social enterprise models in Australia. Social Enterprise Journal, 13(4), 345-361. http://dx.doi.org/10.1108/SEJ-09-2017-0045

Battilana, J., \& Lee, M. (2014). Advancing research on hybrid organizing-Insights from the study of social enterprises. The Academy of Management Annals, 8(1), 397-441. http://dx.doi.org/10.1080/19416520.2014.893615

Battilana, J., Sengul, M., Pache, A. C., \& Model, J. (2015). Harnessing productive tensions in hybrid organizations: The case of work integration social enterprises. Academy of Management Journal, 58(6), 1658-1685. http://dx.doi.org/10.5465/amj.2013.0903

Besharov, M. L., \& Smith, W. K. (2014). Multiple institutional logics in organizations: Explaining their varied nature and implications. Academy of Management Review, 39(3), 364-381. http://dx.doi.org/10.5465/amr.2011.0431

Borzaga, C., \& Defourny, J. (2001). The emergence of social enterprise. London, UK: Routledge.

Borzaga, C., \& Spear, R. (2004). Trends and challenges for co-operatives and social enterprises in developed and transition countries. Trento, Italy: Edizioni 31.

Brewer, C. V. (2016). The ongoing evolution in social enterprise legal forms. In Young, D. R., Searing, E. A., \& Brewer, C. V. (Eds.), The social enterprise zoo: A guide for perplexed scholars, entrepreneurs, philanthropists, leaders, investors, and policymakers (pp. 33-64). Cheltenham, UK: Edward Elgar Publishing.

Chell, E., Nicolopoulou, K., \& Karataş-Özkan, M. (2010). Social entrepreneurship and enterprise: International and innovation perspectives. Entrepreneurship \& Regional Development, 22(6), 485-493. http://dx.doi.org/10.1080/08985626.2010.488396

Chryssochoou, X. (2003). Studying identity in social psychology: Some thoughts on the definition of identity and its relation to action. Journal of Language and Politics, 2(2), 225-241.

Dacin, M. T., Dacin, P. A., \& Tracey, P. (2011). Social entrepreneurship: A critique and future directions. Organization Science, 22(5), 1203-1213. http://dx.doi.org/10.1287/orsc.1100.0620

Dart, R. (2004). The legitimacy of social enterprise. Nonprofit Management and Leadership, 14(4), 411-424. http://dx.doi.org/10.1002/nml.43

Dees, J. G., \& Anderson, B. B. (2006). Framing a theory of social entrepreneurship: Building on two schools of practice and thought. Research on Social Entrepreneurship: Understanding and Contributing to an Emerging Field, 1(3), 39-66.

Dees, J. G. (2018). The Meaning of Social Entrepreneurship. In Hamschmidt, J., \& Pirson, M. (Eds.), Case Studies in Social Entrepreneurship and Sustainability: the oikos collection (pp. 34-42). New York, USA: Routledge. http://dx.doi.org/10.4324/9781351278560-5

Defourny, J., \& Nyssens, M. (2010). Conceptions of social enterprise and social entrepreneurship in Europe and the United States: Convergences and divergences. Journal of Social Entrepreneurship, 1(1), 32-53. http://dx.doi.org/10.1080/19420670903442053

Defourny, J., \& Nyssens, M. (2012). The EMES approach of social enterprise in a comparative perspective. No. 
UCL-Université Catholique de Louvain.

Defourny, J., \& Nyssens, M. (2017). Fundamentals for an international typology of social enterprise models. Voluntas: International Journal of Voluntary and Nonprofit Organizations, 28(6), 2469-2497. http://dx.doi.org/10.1007/s11266-017-9884-7

Defourny, J. (2001). From third sector to social enterprise. In Borzaga, C., Defourny, J. (Eds.), The emergence of social enterprise (pp. 1-28). London, UK: Routledge.

Defourny, J., Hulgård, L., \& Pestoff, V. (2014). Social enterprise and the third sector: Changing European landscapes in a comparative perspective. New York, USA: Routledge. http://dx.doi.org/10.4324/9780203487747

Doherty, B., Haugh, H., \& Lyon, F. (2014). Social enterprises as hybrid organizations: A review and research agenda. International Journal of Management Reviews, 16(4), 417-436. http://dx.doi.org/10.1111/ijmr.12028

Dwivedi, A., \& Weerawardena, J. (2018). Conceptualizing and operationalizing the social entrepreneurship construct. Journal of Business Research, 86, 32-40. http://dx.doi.org/10.1016/j.jbusres.2018.01.053

Evers, A., \& Laville, J. L. (2004). The third sector in Europe. UK: Edward Elgar Publishing. http://dx.doi.org/10.4337/9781843769774

Fauchart, E., \& Gruber, M. (2011) Darwinians, Communitarians and Missionaries: The Role of Founder Identity in Entrepreneurship. Academy of Management Journal, 54(5), 935-957. http://dx.doi.org/10.5465/amj.2009.0211

Fici, A. (2016). Recognition and legal forms of social enterprise in Europe: a critical analysis from a comparative law perspective. European Business Law Review, 27(5), 639-667.

Fitzgerald, T., \& Shepherd, D. (2018). Emerging structures for social enterprises within nonprofits: An institutional logics perspective. Nonprofit and Voluntary Sector Quarterly, 47(3), 474-492. http://dx.doi.org/10.1177/0899764018757024

Galera, G., \& Borzaga, C. (2009). Social enterprise: An international overview of its conceptual evolution and legal implementation. Social Enterprise Journal, 5(3), 210-228. http://dx.doi.org/10.1108/17508610911004313

Germak, A. J., \& Robinson, J. A. (2014). Exploring the motivation of nascent social entrepreneurs. Journal of Social Entrepreneurship, 5(1), 5-21. http://dx.doi.org/10.1080/19420676.2013.820781

Gibbon, J., \& Dey, C. (2011). Developments in social impact measurement in the third sector: scaling up or dumbing down? Social and Environmental Accountability Journal, 31(1), 63-72. http://dx.doi.org/10.1080/0969160X.2011.556399

Guo, C., \& Bielefeld, W. (2014). Social entrepreneurship: An evidence-based approach to creating social value. San Francisco, USA: John Wiley \& Sons.

Haugh, H. (2005). The role of social enterprise in regional development. International Journal of Entrepreneurship and Small Business, 2(4), 346-357. http://dx.doi.org/10.1504/IJESB.2005.007085

Haugh, H. (2006). Social enterprise: Beyond economic outcomes and individual returns. In Mair J., Robinson J., \& Hockerts K. (Eds.), Social entrepreneurship (pp. 180-205). London: Palgrave Macmillan. http://dx.doi.org/10.1057/9780230625655_12

Huang, C. C., \& Donner, B. (2018). Research Report \#40. The Development of Social Enterprise: Evidence from Europe, North America, and Asia. New Brunswick, USA: Rutgers School of Social Work.

Hwang, D. S., Jang, W., Park, J. S., \& Kim, S. (2017). Social Enterprise in South Korea. Social Enterprise Journal, 13(4), 362-375. http://dx.doi.org/10.1108/SEJ-09-2017-0047

Integrated Reporting. The international $<\mathrm{IR}>$ framework. (2013). Retrieved from http://www.integratedreporting.org/resource

Jones, R., Latham, J., \& Betta, M. (2008). Narrative construction of the social entrepreneurial identity. International Journal of Entrepreneurial Behavior \& Research, 14(5), 330-345. http://dx.doi.org/10.1108/13552550810897687

Kerlin, J. A. (2006). Social enterprise in the United States and Europe: Understanding and learning from the differences. Voluntas: International Journal of Voluntary and Nonprofit Organizations, 17(3), 247-263. 
http://dx.doi.org/10.1007/s11266-006-9016-2

Kerlin, J. A. (2010). A comparative analysis of the global emergence of social enterprise. Voluntas: International Journal of Voluntary and Nonprofit Organizations, 21(2), 162-179. http://dx.doi.org/10.1007/s11266-010-9126-8

Kerlin, J. A. (2012). Defining Social Enterprise across Different Contexts. A Conceptual Framework Based on Institutional Factors. Nonprofit and Voluntary Sector Quarterly, 42(1), 84-108. https://doi.org/10.1177/0899764011433040

Kramer, R. M. (2000). A third sector in the third millennium? Voluntas: International Journal of Voluntary and Nonprofit Organizations, 11(1), 1-23.

Kummitha, R. K. R. (2016). Social entrepreneurship: Working towards greater inclusiveness. India: SAGE Publications.

Laville, J. L., \& Nyssens, M. (2001). The social enterprise. Towards a theoretical socio-economic approach. In Borzaga, C., Defourny, J. (Eds.), The emergence of social enterprise (pp. 312-332). London, UK: Routledge.

Leitch, C. M., \& Harrison, R. T. (2016). Identity, identity formation and identity work in entrepreneurship: conceptual developments and empirical applications. Entrepreneurship \& Regional Development, 28(3-4), 177-190. http://dx.doi.org/10.1080/08985626.2016.1155740

Lepoutre, J., Justo, R., Terjesen, S., \& Bosma, N. (2013). Designing a global standardized methodology for measuring social entrepreneurship activity: The Global Entrepreneurship Monitor social entrepreneurship study. Small Business Economics, 40(3), 693-714. http://dx.doi.org/10.1007/s11187-011-9398-4

Littlewood, D., \& Holt, D. (2018). Social entrepreneurship in South Africa: Exploring the influence of environment. Business \& Society, 57(3), 525-561. http://dx.doi.org/10.1177/0007650315613293

Low, C. (2006). A framework for the governance of social enterprise. International Journal of Social Economics, 33(5/6), 376-385. http://dx.doi.org/10.1108/03068290610660652

Mair, J., \& Marti, I. (2006). Social entrepreneurship research: A source of explanation, prediction, and delight. Journal of World Business, 41(1), 36-44. http://dx.doi.org/10.1016/j.jwb.2005.09.002

Marx, A., Cambré, B., \& Rihoux, B. (2013). Crisp-set qualitative comparative analysis in organizational studies. In Fiss P. C., Cambré, B., \& Marx, A. (Eds.), Configurational theory and methods in organizational research (pp. 23-47). Bingley, UK: Emerald Group Publishing Limited. http://dx.doi.org/10.1108/S0733-558X(2013)0000038006

McLoughlin, J., Kaminski, J., Sodagar, B., Khan, S., Harris, R., Arnaudo, G., \& Mc Brearty, S. (2009). A strategic approach to social impact measurement of social enterprises: The SIMPLE methodology. Social Enterprise Journal, 5(2), 154-178. http://dx.doi.org/10.1108/17508610910981734

McMullen, J. S. (2018). Organizational hybrids as biological hybrids: Insights for research on the relationship between social enterprise and the entrepreneurial ecosystem. Journal of Business Venturing, 33(5), 575-590. http://dx.doi.org/10.1016/j.jbusvent.2018.06.001

Mulgan, G., Tucker, S., Ali, R., \& Sanders, B. (2007). Social innovation: what it is, why it matters and how it can be accelerated. London: Young Foundation.

Nguyen, L., Szkudlarek, B., \& Seymour, R. G. (2015). Social impact measurement in social enterprises: An interdependence perspective. Canadian Journal of Administrative Sciences, 32(4), 224-237. http://dx.doi.org/10.1002/cjas.1359

Nicholls, A., Simon, J., \& Gabriel, M. (2015). New frontiers in social innovation research. Basingstoke, UK: Palgrave Macmillan. http://dx.doi.org/10.1057/9781137506801

Noonin, S. (2012). Social Enterprise for Sustainable Development. University of the Thai Chamber of Commerce Journal, 32(4), 196-206.

Ormiston, J., \& Seymour, R. (2011). Understanding value creation in social entrepreneurship: The importance of aligning mission, strategy and impact measurement. Journal of Social Entrepreneurship, 2(2), 125-150. http://dx.doi.org/10.1080/19420676.2011.606331

Peredo, A. M., \& McLean, M. (2006). Social entrepreneurship: A critical review of the concept. Journal of World Business, 41(1), 56-65. http://dx.doi.org/10.1016/j.jwb.2005.10.007 
Pestoff, V., \& Hulgård, L. (2016). Participatory governance in social enterprise. International Journal of Voluntary and Nonprofit Organizations, 27(4), 1742-1759. http://dx.doi.org/10.1007/s11266-015-9662-3

Pestoff, V., Brandsen, T., \& Verschuere, B. (2012). New public governance, the third sector and co-production. New York, USA: Routledge. http://dx.doi.org/10.4324/9780203152294

Poledrini, S. (2014). Unconditional reciprocity and the case of Italian social cooperatives. Nonprofit and Voluntary Sector Quarterly, 44(3), 457-473. http://dx.doi.org/10.1177/0899764013518844

Ragin, C. C., \& Rihoux, B. (2004). Qualitative comparative analysis (QCA): State of the art and prospects. Qualitative Methods, 2(2), 3-13.

Rihoux, B., \& De Meur, G. (2009). Crisp-set qualitative comparative analysis (csQCA). In Rihoux, B. \& Ragin, C.C. (Eds.), Configurational comparative methods: Qualitative comparative analysis (QCA) and related techniques (pp. 33-68). USA: Sage Publications. http://dx.doi.org/10.4135/9781452226569.n3

Rivera-Santos, M., Holt, D., Littlewood, D., \& Kolk, A. (2015). Social entrepreneurship in sub-Saharan Africa. Academy of Management Perspectives, 29(1), 72-91. http://dx.doi.org/10.5465/amp.2013.0128

Rodger, J. J. (2000). From a welfare state to a welfare society. Hong Kong: Macmillan Press LTD.

Salamon, L. M., \& Sokolowski, S. W. (2016). Beyond nonprofits: Re-conceptualizing the third sector. International Journal of Voluntary and Nonprofit Organizations, 27(4), 1515-1545. http://dx.doi.org/10.1007/s11266-016-9726-z

Sdrali, D., Goussia-Rizou, M., \& Sarafi, V. (2016). Exploring the work environment in Greek social enterprises: a first overview. International Journal of Entrepreneurship and Small Business, 28(4), 451-467. http://dx.doi.org/10.1504/IJESB.2016.077577

Sengupta, S., Sahay, A., \& Croce, F. (2018). Conceptualizing social entrepreneurship in the context of emerging economies: An integrative review of past research from BRIICS. International Entrepreneurship and Management Journal, 14(4), 771-803. http://dx.doi.org/10.1007/s11365-017-0483-2

Sepulveda, L. (2015). Social enterprise - a new phenomenon in the field of economic and social welfare? Social Policy \& Administration, 49(7), 842-861. http://dx.doi.org/10.1111/spol.12106

Sieger, P., Gruber, M., Fauchart, E., \& Zellweger, T. (2016). Measuring the social identity of entrepreneurs: Scale development and international validation. Journal of Business Venturing, 31(5), 542-572. http://dx.doi.org/10.1016/j.jbusvent.2016.07.001

Spear, R., \& Bidet, E. (2005). Social enterprise for work integration in 12 European countries: a descriptive analysis. Annals of Public and Cooperative Economics, 76(2), 195-231. http://dx.doi.org/10.1111/j.1370-4788.2005.00276.x

Stets, J. E., \& Burke, P. J. (2000). Identity theory and social identity theory. Social Psychology Quarterly, 63(3), 224-237. http://dx.doi.org/10.2307/2695870

Stets, J. E., \& Serpe, R. T. (2013). Identity theory. In DeLamater, J. \& Ward, A. (Eds.), Handbook of social psychology (pp. 31-60). Dordrecht: Springer. http://dx.doi.org/10.1007/978-94-007-6772-0_2

Stevens, R., Moray, N., \& Bruneel, J. (2015). The social and economic mission of social enterprises: Dimensions, measurement, validation, and relation. Entrepreneurship Theory and Practice, 39(5), 1051-1082. http://dx.doi.org/10.1111/etap.12091

Townsend, D. M., \& Hart, T. A. (2008). Perceived institutional ambiguity and the choice of organizational form in social entrepreneurial ventures. Entrepreneurship Theory and Practice, 32(4), 685-701. http://dx.doi.org/10.1111/j.1540-6520.2008.00248.x

Urbano, D., Ferri, E., Peris-Ortiz, M., \& Aparicio, S. (2017). Social Entrepreneurship and Institutional Factors: A Literature Review. In Peris-Ortiz, M., Teulon, F., \& Bonet-Fernandez, D. (Eds.), Social Entrepreneurship in Non-Profit and Profit Sectors (pp. 9-29). Cham: Springer. http://dx.doi.org/10.1007/978-3-319-50850-4_2

Weerawardena, J., \& Mort, G. S. (2012). Competitive strategy in socially entrepreneurial nonprofit organizations: Innovation and differentiation. Journal of Public Policy \& Marketing, 31(1), 91-101. http://dx.doi.org/10.1509/jppm.11.034

Wilson, F., \& Post, J. E. (2013). Business models for people, planet (\& profits): exploring the phenomena of social business, a market-based approach to social value creation. Small Business Economics, 40(3), 
715-737. http://dx.doi.org/10.1007/s11187-011-9401-0

Wry, T., \& York, J. G. (2017). An identity-based approach to social enterprise. Academy of Management Review, 42(3), 437-460. http://dx.doi.org/10.5465/amr.2013.0506

Young, D. (2008). Alternative Perspectives on Social Enterprise. In Cordes, J.J., Steuerle, C.E. (Eds.), Nonprofits \& Business (pp. 21-46). Washington D.C.: The Urban Institute.

Zahra, S. A., Gedajlovic, E., Neubaum, D. O., \& Shulman, J. M. (2009). A typology of social entrepreneurs: Motives, search processes and ethical challenges. Journal of Business Venturing, 24(5), 519-532. http://dx.doi.org/10.1016/j.jbusvent.2008.04.007

\section{Copyrights}

Copyright for this article is retained by the author(s), with first publication rights granted to the journal.

This is an open-access article distributed under the terms and conditions of the Creative Commons Attribution license (http://creativecommons.org/licenses/by/4.0/). 